\section{The correlation of foreign language proficiency, employment and regional competitiveness in the North Great Plain Region of Hungary}

\author{
Hajdú Zita \\ Debrecen University Centre of Agricultural Sciences, \\ Department of Agricultural, \\ Technical Language and Communication Studies, Debrecen \\ hajdu@agr.unideb.hu
}

\section{SUMMARY}

Employment is one of the basic factors when evaluating a region's competitiveness. Boosting employment figures will also increase individual income. However, the creation of jobs alone will not solve the problems of unemployment, as labour force with skills matched to labour market demands should also be available. Continuous development of the labour force, adjusted to recent needs in the labour market, can contribute to a region's competitiveness. Mismatches between education and labour market requirements would be too expensive, especially for backward regions like the North Great Plain Region of Hungary. Foreign language education should also be adapted to the changing economy when selecting target languages and language skills. A workforce equipped with contemporary and needed second language skills can be an element in making a region attractive for investors. Although current trends show signs of improvement, Hungary and especially the North Great Plain Region still does not have much to offer in this respect. The paper examines the reasons for the low level of second language acquisition among Hungarians and the population of the North Great Plain Region and explores the ways foreign language knowledge could promote economic development.

Keywords: regional competitiveness, employment, human capital development, education, needs analysis, adjusted skills, foreign language skills, second languages required by the labour market

\section{THE CONTRIBUTION OF EDUCATION TO IMPROVING EMPLOYMENT}

\section{The role of education in the employment policy of the European Union}

As we are approaching 2010 the Lisbon Strategy of the European Union and its objectives are receiving considerable media attention. In 2000 the European Council resolved ,to make the EU the most competitive and dynamic knowledge-based economy in the world capable of sustainable economic growth with more and better jobs and greater social cohesion by 2010 ". The concrete goal of raising EU employment rate to $70 \%$ was also set. In 2002 a further objective of making Europe the world leader with respect to the quality of its education and training systems was agreed on by the European Council (net 1). These challenges require sizeable efforts and adequate measures from both EU level and member state level administration. In terms of enhancing employment the European Union's activity is primarily based on the European Employment Strategy, which dates back as early as 1997 . Since the 1990s, the reduction of unemployment has been a priority for the European Community.
This lead to the first special employment summit (Luxemburg, 1997) in the history of the EU where the basis of the European Employment Strategy was laid down in the form of the EU's first guideline on employment policy (1998). Out of the four pillars of the guideline the improvement of employability and the adaptability of workers and enterprises (net 1) emphasises the role of vocational education and training. The most recent (2005-2008) guidelines for growth and jobs added the following goals to be integrated in the education strategies of member states:

- „to improve matching of labour market needs" and

- „to adapt education and training systems in response to new competence requirements" (net 2).

The overall goal of expanding and improving investment in human capital and lifelong learning (net 2) is the task of the European Union and national administrations.

\section{Matching labour market needs and educational content}

Apart from financial support the requirements of the demand side also need considering. The role of harmonising labour market needs with the educational content should be a shared role of governments, companies and training institutions. These actors of the labour market, together with employees all benefit from proper needs analyses.

The government has to provide for smooth functioning of the labour market and prevent financial and social losses resulting from mismatches between training and labour market demands.

Companies must be aware of shortage or surplus in specific occupations, often at regional level. This information is essential for big firms when deciding on their research and development or personnel strategies and also when they choose locations for their production plants (Hilbert and Schömann, 2004). The quality and qualifications of local labour force is a crucial factor for companies in the service sector or with high-tech or research and development activities (Lengyel and Rechnitzer, 2004).

Educational and training institutions more and more depend on the number of enrolled students, i.e.: subsidies from the government or tuition fees. Consequently, they ought to ascertain that their courses satisfy knowledge niches in the labour market. 
The information on sector or regional needs for occupations, qualifications or skills is beneficial for individuals when deciding about courses or schools to be enrolled in or choosing locations for work.

A research model for the identification of qualification and skill needs and the implementation of the findings is presented in Figure 1. The research model of the Social Science Research Centre in Berlin (WZB) investigates two points: comparison and analysis of needs prediction and the ways to implement the findings. The participation of actors from the labour market is also necessary as they can identify the possible institutional barriers in the execution stage. The research is clustered in three areas. Theories are tested for their relevance to anticipating needs at country level and two other clusters examine the need for regional and sector specific forecasting. Topics overlapping the three clusters are: the effect of technological progress on skills demanded by the labour market, special attention is paid to SMEs lacking the resources for needs analyses and further training, in addition quantitative and qualitative methods are involved in the whole research project (Hilbert and Schömann, 2004).

Figure 1: Qualification needs: WZB approach

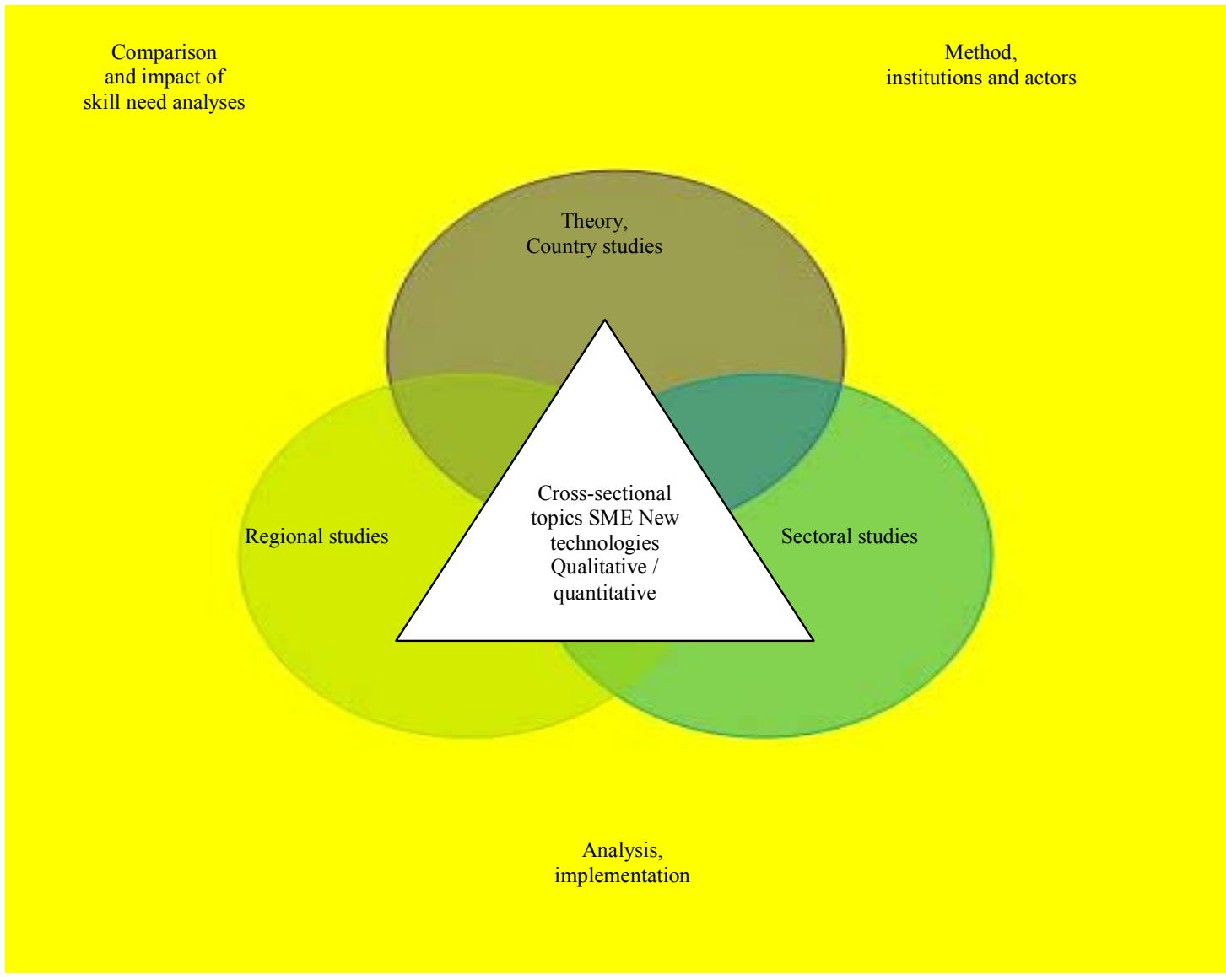

Source: Hilbert and Schömann, 2004

\section{HUMAN CAPITAL AS A REGIONAL ISSUE}

New ideas and technology, modern management strategies and methods are needed to boost a region's economic productivity. Human capital equipped with up-to-date knowledge is a key factor in integrating new technologies in the economy and working out new, marketable technologies of its own. The territorial concentration of highly skilled professionals will multiply the creation of technological advances (Lengyel and Rechnitzer, 2004). Educational institutions have a major integration role.

Figure 2 shows the interactions between the development of human capital and the growth of local economy. The learning motivation and the number of students in schooling are affected by, besides some other factors, the employment and career possibilities in the local economy. At the same time enrolment determines work force skills, labour productivity, and the economic performance of a region. The economic performance strongly influences the quantity and quality of inward migrant employees and allows for further training or cross training activities. A quality improvement in the qualification and skill mix of employees will better the human capital stock of a region or an area (Izushi and Huggins, 2004). 


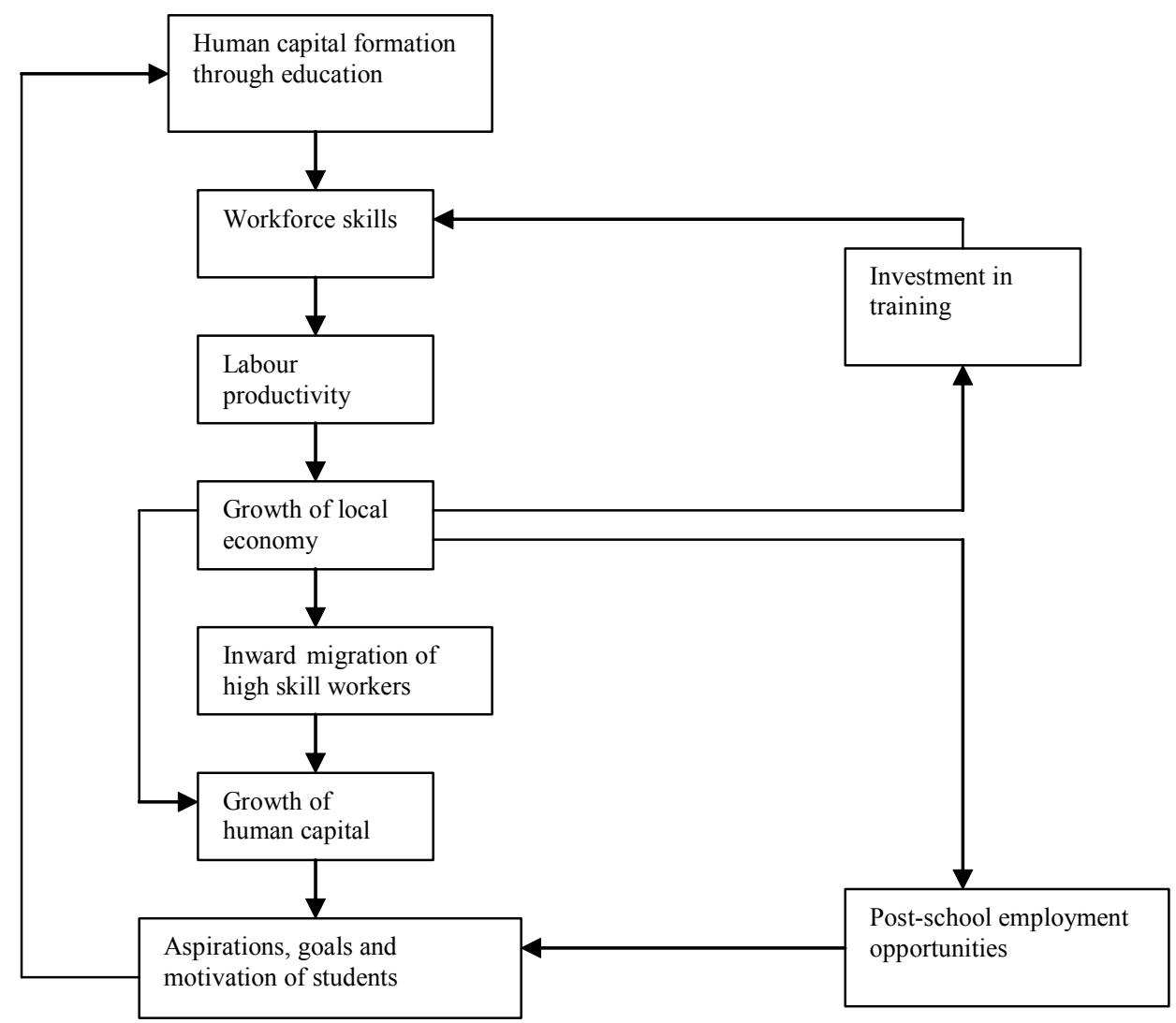

Source: Bradley and Taylor, 1996 in: Izushi and Huggins, 2004

Labour force with knowledge base according to present and future day requirements is the vehicle of local initiatives also. The EU's support system is based on applications and experts trained to meet the current demands can better interpret calls for applications and they are capable of writing better applications.

Underdeveloped regions in need of investors could particularly benefit from the improvement of human resources, for this element would make a region more attractive for potential investors who would provide jobs for the unemployed and place orders for the enterprises and via this multiplier effect the local economy would grow. Based on several economic factors (GDP, employment, number of enterprises, size of industrial production, lagging behind infrastructure) the North Great Plain region of Hungary is considered to be one of the most backward regions of Hungary. The number of business organizations increases slowly and invested foreign capital for a single inhabitant amounts merely to $55 \%$ of the national average (Harsányi et al., 2005). The lack of job creating large investments exerts its influence on several indices in the region. According to the first quarterly report of the Hungarian Statistical Office unemployment was highest with $11.7 \%$ in the North Great Plain Region from among the seven
Hungarian regions (KSH, 2006). Besides other regional development instruments education would be fundamental to economic progress and also the strengthening of social capital.

\section{FOREIGN LANGUAGE SKILLS AS KEY COMPETENCIES FOR EMPLOYMENT}

The knowledge of foreign languages, especially technical language skills, is a key element in employability. Higher education is almost exclusively the single base of technical language education. In present day economic and social conditions foreign language teachers face new challenges: besides the development of classical foreign language skills they need to work out taskoriented, creativity inspiring curricula which apply an appropriate proportion of technical and linguistic parts and meet the expectations of a multicultural working environment (Feketéné, 2002).

In a survey on the ten attractive properties of company premises the representatives of large companies ranked the category of labour force second after regional accessibility, and labour force category in this case included language skills besides qualifications and willingness for adaptation (Koltai, 2006). 
Learning a language also means learning a culture and this way dismantling barriers that divide people. This idea might have been in the mind of EU legislators when they gave high priority to the promotion of language learning. At the Lisbon and Barcelona (2000 and 2002) summits foreign language proficiency was acknowledged as a "new basic skill" to the aims of economic progress and social cohesion and the European Council included foreign language learning in the thirteen objectives of the Objectives Process in the Lisbon Strategy (net 3).

In July 2003 the European Commission announced a new action plan (net 3) to inspire learning languages and to support language diversity. The documents in the framework of this action plan place a high emphasis on linguistic knowledge in relation to mobility and economic competitiveness in the EU. On behalf of the Directorate General for Press and Communication a survey was prepared in 2005 which studied language proficiency in the $25 \mathrm{EU}$ member states.

The most significant factor highlighted by surveys is whether employees have conversationlevel general language skills (Figure 4). However, this level is increasingly unsatisfactory for access to employment. Employers tend to expect special, practice-oriented and appropriate (language) skills required by given tasks. European employees are aware of this demand. Surveys on EU member states show that in the years after the millennium the significance of foreign language learning for vocational, employment, business or study purposes has considerably risen. In an EU survey in 2005 data from 2001 and 2005 were compared. It revealed that in $200126 \%$ of the respondents indicated employment-oriented language skills as a motivation for learning a new language, whereas it was $32 \%$ in 2005. Job seeking in a foreign country was a motivating factor for merely $15 \%$ in 2001, this amounted to $27 \%$ in 2005 and the number of those, who started to study another new language as a result of foreign study opportunities, increased from $6 \%$ to $14 \%$. A reverse tendency can be observed in terms of personal ambition and craving for knowledge $(-10 \%)$ and language learning for the purposes of tourism $(-8 \%)$. The survey results coincide with language teachers' experience. In language education, the spirit of the age and pragmatic objectives tend to predominate. The future enhancement of this trend is prognosticated by the percentage of the answers to the question: „Why should youngsters learn foreign languages?". The majority $(73 \%)$ mentioned better employment opportunities, while the second option on the list („Because a lot of people speak this language in the world") was chosen by only $38 \%$ of the respondents. Answers to questions concerning current foreign language use showed the increasing frequency of using foreign language skills at work (work-related correspondence, telephoning, etc.) between 2001 and 2005 (net 4). This tendency is confirmed by the figures of the graph below (Figure 3) which shows which languages are found to be most useful by Europeans. „The most useful language", English is the number one working language in the whole of Europe.

Figure 3: The usefulness rank of foreign languages based on answers of European individuals

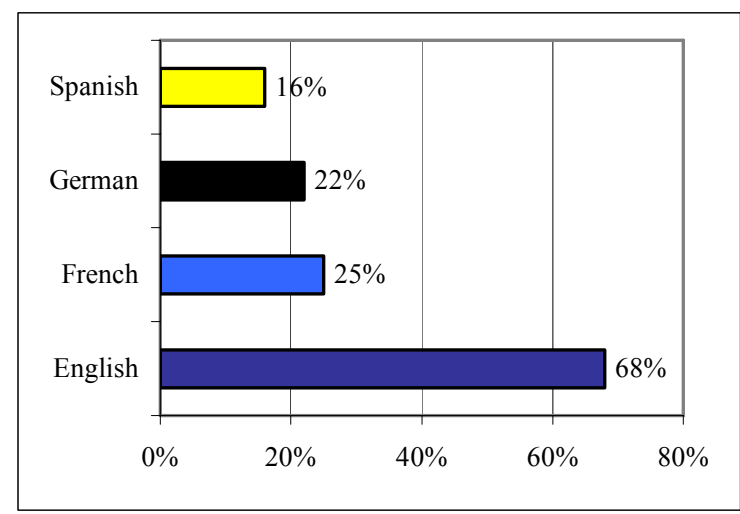

Source: edited by the author on the basis of the homepage (net 4)

Figure 4: The proportion of people in countries of the European Union speaking at least one second language (2005)

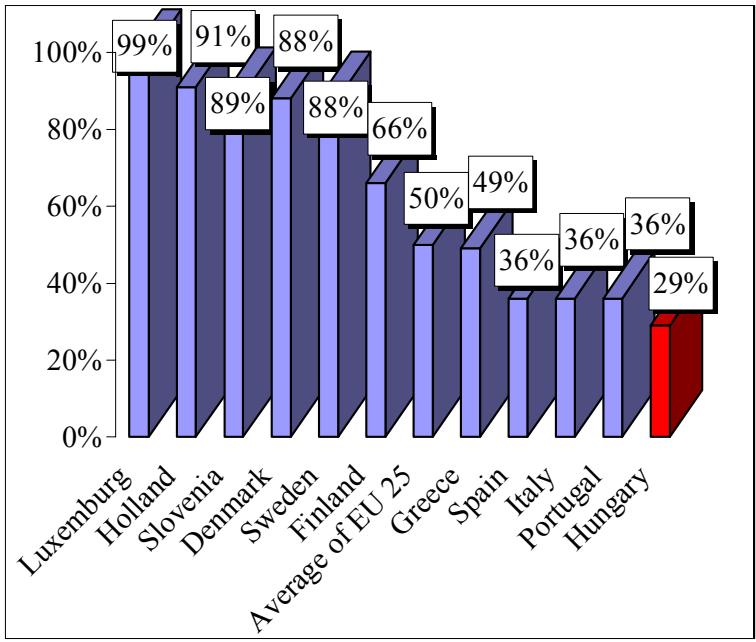

Source: edited by the author on the basis of the homepage (net 5)

\section{The relevance of needs analysis and motivation in language learning}

It can be concluded that foreign-language studies tend to be related to work and this fact enhances the role of needs analyses integrated in language teaching and especially in technical language teaching. We can distinguish objective and subjective needs analyses. Objective needs analyses include investigations on those situations in communication, where learners are likely to use the language. Subjective needs are specified by learners themselves (Brindley, 1986). Situations of communication examined in objective needs analyses are determined by the external environment, the labour market.

Organisers of education and educators need to constantly monitor the demands and new tendencies of users, and compile the content of language courses accordingly (Wiwczaroski, 2003). 
The „expectation model” (Rubenson, 1975; Howard, 1989) states that advantages hoped to be gained from learning provide energy for a person's behaviour and the prospective values of results show the way towards proper behaviour. Learning facilitates the development of a connection between behaviour and expected outcomes. The utilisation of the above theories would definitely contribute to successful language learning, especially in technical language teaching and adult education.

\section{HUNGARY'S POSITION IN EUROPE IN TERMS OF SECOND LANGUAGE SKILLS}

National results of the above mentioned European survey on language knowledge are shown in Figure 4. Not all the 25 countries are included in the graph but the best and worst performing countries are presented.

Having a closer look at the data of the $25 \mathrm{EU}$ member states, Luxemburg's positions on top of the list with her result of $99 \%$ concerning the knowledge of a second language is not startling, as several official languages are used in the country. The reason for the similarly high indices in the Netherlands $(91 \%)$, Scandinavian and Slavic countries can be explained with the relations of language families, as native speakers of Dutch or Swedish can master German or English faster and the same holds for Slavic language speakers as well. The excellent performance of Finland might be especially thought provoking for Hungarians. Similarly to Hungarian, the Finnish language is not included in the family of Indo-European languages, and Finnish native speakers face the same linguistic difficulties (different word-formation, sentence construction, etc.) as Hungarians. However, the percentage of population concerning the knowledge of at least one second language is more than double than in Hungary.

The survey triggered harsh media coverage on Hungary's outstandingly poor ranking within the 25 countries, as Hungarian foreign language education has received considerable support and attention in Europe in the past 15 years. Despite all these efforts, all the surveys on foreign language skills in the past few years indicated that Hungary was in the last place out of the 10 members joining the EU in 2004 (net 4).

\section{Insufficiencies and problems in foreign language education to date}

The primary factors of failure are the low number of exposure to situations requiring foreign language skills, even subtitled films are almost non-existent on Hungarian TV-channels, the translation and grammar-oriented school education and the forced teaching of two foreign languages in secondary schools. Technical literature challenges the fact that the efficiency of foreign language knowledge is measured in terms of the number of successful language exams and raises the question whether excessive exam-orientated teaching itself resulted in the poor level of practical language skills. Certain language exams particularly focused on grammatical and translation skills and knowledge (Petneki, 2002). With the extension of the language exam market this dominancy is expected to decrease. Further hindrances for efficiency are heterogeneous, large language groups and language teaching prolonged for too many years with insufficient numbers of language classes, reducing student motivation and interest. As a result of excessively heterogeneous groups some students have to start their language studies from the beginning several times, thus accumulating factors counteracting motivation (Petneki, 2002).

\section{FOREIGN LANGUAGE COMPETENCIES IN THE NORTH GREAT PLAIN REGION OF HUNGARY}

\section{Analysis of the most recent figures}

As the most recent regional data in this topic are available from the census in 2001, European and national data also from 2001 are used for comparison (Figure 5).

Figure 5: Proportion of the population commanding at least one second language (2001)

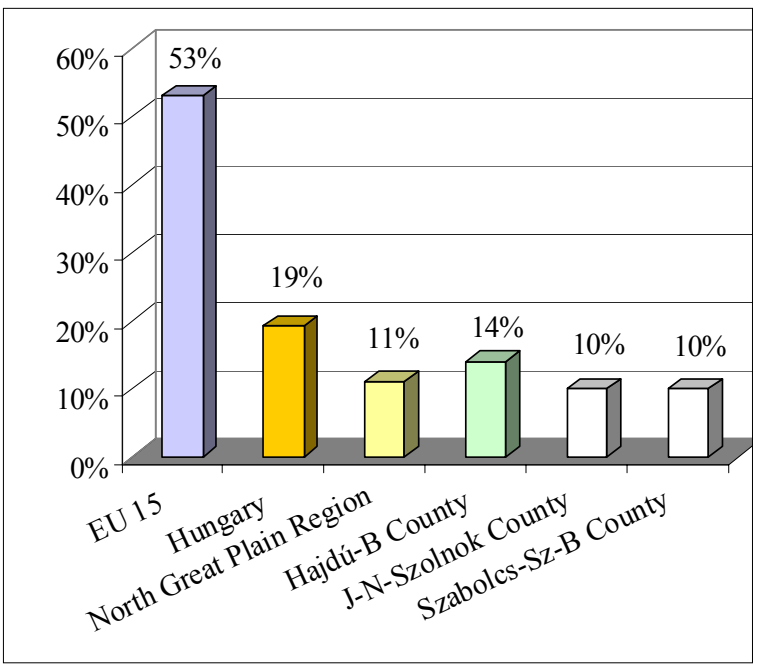

The examination of data referring to Hungary in Figure 4 and 5 suggests that the number of foreign language speakers has considerably increased in Hungary. Although this increasing tendency emerged from 1960 (Table 1), the almost unbelievable development in the four years between 2001 and 2005 has been the result of Hungary's EU accession in 2004, newly opened employment opportunities in mostly the English speaking world and the stimulating force of the obligatory foreign language certificate as one of the requirements of earning degrees for more and more students. The comparison is impressive in spite of the fact that different institutions conducted the survey. However, it must be mentioned that the average of the North Great Plain Region is only about one-fifth of the level 
surveyed in the $15 \mathrm{EU}$ countries. Out of Hungarian regions, the rate of foreign language speakers is the lowest here. The reasons can be grouped in three categories.

- Low level of education: A part of university and college graduates, especially from the classic faculties of arts and sciences leave the region (Röfi, 2006), whereas the language skills of those who possess higher qualifications, are usually better (Figure 6.). It also raises the problem of richer areas benefiting from educational investment by poorer regions.

- Low income level: from this viewpoint the North Great Plain Region was ranked the last but one in 2006 (KSH, 2006) and this restricts travels and language learning opportunities abroad.

- The lack of appropriate motivation: very few foreign firms providing employment potentials for a large number of people have settled in the region, which would incite local inhabitants for learning languages in the hope of job opportunities or higher income. At the same time, this is a reciprocal process: unskilled labour force with poor or no language skills at all do not attract foreign investors in the region.

Hajdú-Bihar County's best performance from among the three counties in the region is primarily due to the role of Debrecen as a cultural and educational centre. The knowledge centre role of Debrecen University is manifested in several areas of the region's economic life; mostly in the qualification level of human resources in the county and the region (Nagy and Baranyi, 2005).

\section{Advances in the past decades}

Based on the estimation of the whole region, the comparison of data from the past decades promises a more hopeful tendency (Table 1).

Table 1

Knowledge of at least one foreign language in percentage of the population (1960-2001)

\begin{tabular}{lrrrr}
\hline & 1960 & 1980 & 1990 & 2001 \\
\hline Hungary & 8,7 & 7,0 & 9,1 & 19,2 \\
North Great Plain Region & 2,0 & 2,2 & 3,8 & 11,0 \\
Hajdú-Bihar County & 2,9 & 3,3 & 5,1 & 14,0 \\
Jász-Nagykun-Szolnok County & 1,4 & 1,7 & 3,1 & 10,0 \\
Szabolcs-Szatmár-Bereg County & 1,8 & 1,4 & 3,1 & 10,0 \\
\hline Source: KSH
\end{tabular}

Source: KSH, 1960, 1980, 1990, 2001

Following the census of 1980 , but especially the one in 1990, a sharp rise has taken place which has been the most dynamic in the North Great Plain out of the seven regions. This dynamic development is markedly conspicuous as regards English language: 1319 persons spoke English out of the region's population in 1960 whereas 92834 in 2001 and this number increased from 723 to 45098 in Hajdú-Bihar County.

\section{The importance of particular foreign languages} from regional development point of view

The three working languages of the European Union are at the same time the three most widely spoken second languages in the European Union (net 4). The incidence of these languages in the North Great Plain Region of Hungary is presented in Table 2.

Table 2

The incidence of English, French and German languages in the North Great Plain Region of Hungary (2001)

\begin{tabular}{|l|r|r|r|}
\hline & English & French & German \\
\hline EU 15 & 41.0 & 19.0 & 10.0 \\
\hline Hungary & 9.2 & 1.0 & 9.4 \\
\hline North Great Plain Region & $\mathbf{6 . 0}$ & $\mathbf{0 . 6}$ & $\mathbf{4 . 7}$ \\
\hline Hajdú-Bihar County & 8.2 & 0.7 & 5.9 \\
\hline J-N-Szolnok County & 5.5 & 0.5 & 4.7 \\
\hline Szabolcs-Sz-B County & 4.2 & 0.4 & 3.6 \\
\hline
\end{tabular}

Source: KSH, 2001

Out of these three English is the most well known in both the EU and the North Great Plain Region of Hungary. The reasons for the popularity of English are most obvious in Hajdú-Bihar County due to the fact that English has become the language of sciences and scientific activities, the „new age Latin” and Debrecen is a university town. Apart from this, the reasons which have allowed English to be the number one language in the world also influence the language learning trends in the North Great Plain Region. These influencing factors are the following: the language of communication is predominantly English in the world of business; the entertainment industry and mass communication have been gaining a bigger and bigger market share from world economy and the major role of the US in the world's economy and politics. In 2001 English was the most popular second language in the EU, with $41 \%$ and together with English as a mother tongue $51 \%$ of Europeans spoke the language. In the same year 9.2\% of Hungarians were reported to speak English and unusually English finished in second place after German (9.4\%) from among second languages spoken by Hungarians. Although the difference is negligible $(0.2 \%)$ and considering the above mentioned tendencies the order of the two foreign languages is likely to change. Especially because of the trends already referred to, thorough English language proficiency would be an inevitable asset for individuals and companies aspiring to be successful in the world of business or science. It will be difficult for a region to be or remain attractive for investors if the owners or their representatives will not be able to communicate with the people in the company's environment (employees, suppliers, business partners, public officials, etc.) and at present the general language of communication, the lingua franca in Europe is English.

French was the second most often spoken language in the European Union in 2001. 
It should be noted though that data related to the speakers of French have changed the most since 2001: based on survey results from 2005 the percentage of people speaking French as a second language was only between 11 and 14 (net 4). Even if one considers a declining tendency in the incidence of French as a foreign language, speaking or at least understanding this language would definitely be useful for the Brussels representatives of the regions as, including native speakers, still $26 \%$ of the citizens of the EU speak this language and it is very often an instrument for informal channels of communication in the EU bureaucracy and thus an important tool for lobbying.

Results concerning the incidence of German language in Hungary are much more reassuring. In 2001 it was the third most well known foreign language, with $10 \%$, in the fifteen countries of the European Union but the newly joined Eastern European states contributed a lot to the rise of this figure to $14 \%$ and raising German to second place in 2005 (net 4) when $32 \%$ of the population, including the native speakers, was reported to speak German. Similarly to other Eastern European countries German has been a most useful foreign language in tourism and commerce in Hungary also. It can be explained by the high percentage of German speaking tourists in Hungarian spas and the dominance of German and Austrian firms in Hungary's foreign trade activities. The Foreign Direct Investment from the German speaking areas to Hungary is considerable: in 2003, out of the 15 states of the EU, Germany had the highest amount of FDI assets invested in Hungary (9 488 million EUR) and after Holland (4 177 million EUR) Austria was the third (3 453 million EUR) (EU, 2006). These phenomena have raised German to $10 \%$ incidence and to be the most widely spoken foreign language in Hungary. At the same time the geographical location of the regions also plays a role in the popularity of foreign languages: in the western regions of Hungary German is and has been the most often spoken foreign language whereas in the eastern regions it is English. In 2001 the ratio of those speaking English and German was $6.0 \%$ to $4.7 \%$ in the North Great Plain Region and $6.3 \%$ to $14.7 \%$ in the WestTransdanubian Region (KSH, 2001). These figures well reflect the expansion of German, Austrian and Swiss companies and tourists.

In the North Great Plain Region of Hungary the most widely spoken foreign languages show the following order: 1. English (6\%), 2. German (4.7\%), 3. Russian $(1.8 \%)$, 4. Romanian $(0.6 \%)$, 5. French $(0.57 \%), 6$. Italian $(0.22 \%)$ and 7 . Ukrainian $(0.20 \%)$ (KSH, 2001). Low incidence of the languages of neighbouring countries question whether all possibilities of geographical closeness have been exploited. After the accession of Romania the transit function of the North Great Plain will very probably increase and this will offer a chance for economic progress. In order to make regions on both sides of the border capable of performing and benefiting from these transit roles the backwardness ought to be reduced and interregional cooperation would be expedient tools for this purpose (Baranyi and Nagyné, 2005). The need and possibilities for more frequent business activities and the possible benefits of joint applications upgrade the value of speaking and understanding each other's language. The interregional cooperation between Austria and Hungary has accumulated tremendous experience, development ideas and implementation lessons for the past fifteen years and all these could be transmitted to the Balkan countries. Hungary has a good chance of becoming one of the two leading states in the CADSES (Central Adriatic Danubian South-Eastern European Space) region - with Austria aspiring to have the other leading position. In this case Hungarian experts and relevant institutions, including not only development agencies but also local governments, business organisations and research institutes could play a central role in the construction, implementation and monitoring of development programs (Rechnitzer, 2006).

\section{Language skills by age groups}

The striking feature of the age group categorization (Kissné, 2003) is the outstanding performance of the group between 15 and 39 years of age compared to the older generations and especially in the case of English. They make up more than two thirds of those who speak English in the North Great Plain Region. With respect to the national figures one can predict a rising tendency since $18.4 \%$ of the 15-39 age group spoke English in 2003 but this figure rose to $52 \%$ among those who finished first year in higher education (KSH, 2003). Language learning of students is considerably influenced by the extra scores they can gain at the entrance procedure for successfully completed language exams and the intermediate or conversational level language exam requirement for university or college degrees respectively. The possibility of working abroad also encourages mainly young generations to acquire foreign languages. The increasing figures for foreign language competency in young generations are projecting a more favourable picture for this quality element of future Hungarian human capital.

In the North Great Plain Region the most well known foreign language in the group 40+, not surprisingly, was Russian which incidence is showing a falling tendency decreasing with age. As Russia is a huge market with numerous niches for Hungarian, especially agricultural, products, the learning and teaching of Russian would deserve more attention.

\section{The correlation between qualification levels and foreign language competency}

In respect of the connection between qualification levels and foreign language knowledge, it can be established that a higher qualification normally involves a higher level language proficiency also (Figure 6). 
Figure 6: The correlation between qualification levels and foreign language competency in the North Great Plain region (2001)

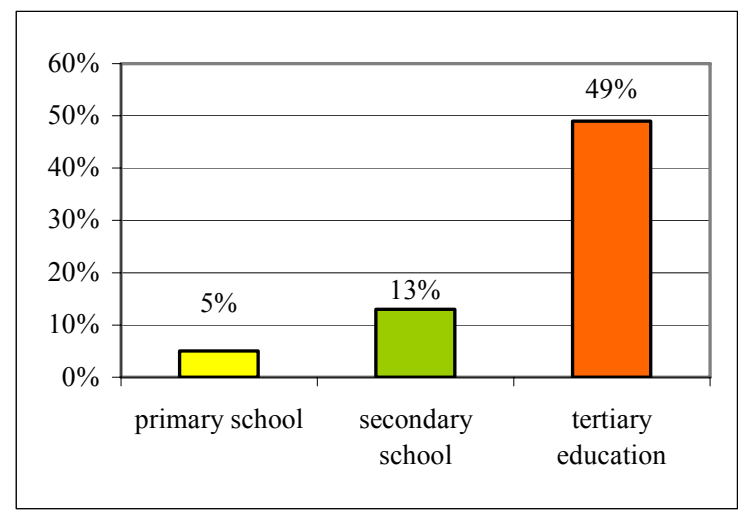

Source: KSH, 2001

The above mentioned education incentives have had an influence on the popularity of language learning since the change of the regime. From employment point of view the low level of language proficiency measured among those having finished only secondary school is unfavourable, for the number of jobs requiring secondary level qualification but at least intermediate level language skills is rising. The availability of workforce with the required skills could make the North Great Plain Region more attractive for investors of, for example, logistic centers and call centres.

\section{The impact of foreign language proficiency on employment}

Examining the relationship between employment status and language command (Figure 7) it can be ascertained that employees have better language skills compared to those of the unemployed and promotion opportunities show relation to language proficiency. The fact that the majority of big companies in Hungary have foreign owners, who would like to be able to communicate with their managers, reinforces the statement above. In the case of the three working languages of the EU the above mentioned correlations were even more forceful: the percentage of foreign language knowledge was double among employees compared to the figure among the unemployed. In respect of these languages the average measured among managers and the intelligentsia was three times more than the total average of the employees (Table 3).

\section{CONCLUSION}

Foreign language proficiency has become one of the key competencies in the labour market and key data when evaluating the labour force of a region. With respect to the role of language skills in regional development and employment policies, the priority task should be to gain knowledge on the user side and serve its interests. The capital attraction potential of a region could be largely improved by a labour force capable of continuous adaptation and in possession of up-to-date (language) skills. Surveys similar to the above mentioned are also read by the managers of job-creating large foreign companies and these facts can influence their decisions when locations are selected for their operation.

Figure 7: The relationship between employment status and foreign language command in the North Great Plain Region of Hungary (2001)

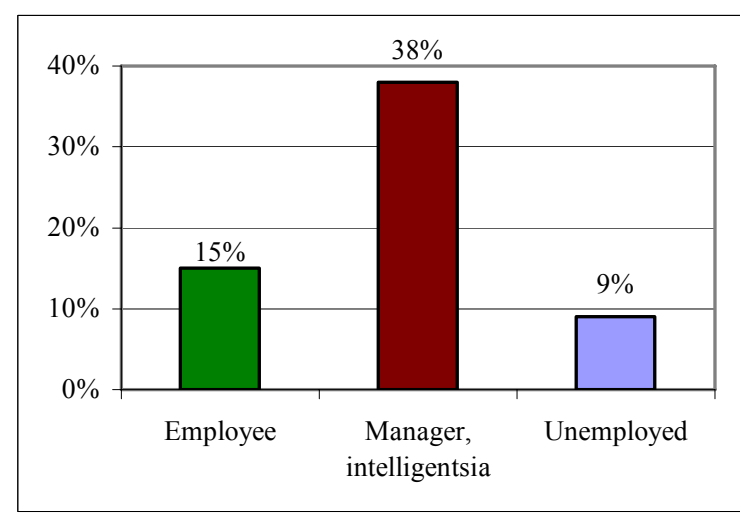

Source: KSH, 2001

Table 3

The percentage of employment categories speaking English, German or French in the North Great Plain Region (2001)

\begin{tabular}{|l|r|r|r|}
\hline Foreign language & English & German & French \\
\hline Total of employees & 7.6 & 5.9 & 0.8 \\
\hline $\begin{array}{l}\text { Managers, intelligentsia } \\
\text { (Out of the total of employees) }\end{array}$ & 24.6 & 15.4 & 2.3 \\
\hline Unemployed & 3.6 & 3.0 & 0.4 \\
\hline
\end{tabular}

Source: KSH, 2001

\section{REFERENCES}

Baranyi B.-Nagyné D.D. (2005) Határmenti együttmüködések szerepe és lehetőségei az Észak-alföldi Régióban. In: Baranyi B. (szerk.) Közelítések. A határon átnyúló kapcsolatok kilátásai és a mezőgazdaság regionális kérdései az Európai Unió keleti peremén, Szerk: Baranyi B. Debrecen, MTA Regionális Kutatások Központja. 137-146.

Brindley, G. (1986): Needs Analysis and Objective Setting in the Adult Migrant Education Program. Sydney.
Feketéné S.M. (2002): Nyelvi kompetencia elvárások a multikulturális munkaerö-piacon. Agrártudományi Közlemények 1.

Harsányi E.-Harsányi G.-Nagy A.J. (2005): Területi fejlettségi különbségek Magyarországon és az Észak-alföldi Régióban. Agrártudományi Közlemények. 18. 62-71.

Hilbert, C.-Schömann, K. (2004): The need for early identification of future skill requirements in the European Union. In: Identifying skill needs for the future - From research to 
policy and practice, Cedefop Reference series, 52, Ed.: Tessaring, M., Luxembourg, 55-59.

Howard, K.W. (1989): A comprehensive expectancy motivation model: Implications for adult education and training. Adult Edue. Q. 39.4. In: Kozma T. (szerk) Felnőttképzés és gazdaság. Pallas Debrecina 11: Debrecen.

Izushi, H.-Huggins, R. (2004): Empirical analysis of human capital development and economic growth in European regions. In: Impac of education and training. Third report on vocational training research in Europe, Cedefop Reference series, 54, Ed.: Descy, P.-Tessaring, M., Luxembourg, 86-87.

Kissné M.M. (2003): Észak-Alföld népességének idegennyelvismerete. Hajdú-Bihar megyei statisztikai tájékoztató, 2003/1. Központi Statisztikai Hivatal. Hajdú-Bihar Megyei Igazgatósága. 56-60.

Koltai Z. (2006): A magyar lakosság és vállalati szféra lakó-, illetve telephelyválasztásának szempontjai. Területi Statisztika. 2006. május. 240-254.

Lengyel I.-Rechnitzer J. (2004): Regionális gazdaságtan. Dialóg Campus Kiadó, Budapest-Pécs, 100-101.

Nagy J.-Baranyi B. (2005): A Debreceni Egyetem szerepe a regionális fejlődésben. In: Buday-Sántha A.-Erdősi F.Horváth Gy. (szerk.) Évkönyv 2004-2005. II. kötet. Környezetvédelem, regionális versenyképesség, fenntartható fejlődés. Pécsi Tudományegyetem, Regionális Politika és Gazdaságtan Doktori Iskola, Pécs, 203-213.
Petneki K. (2002): Az idegen nyelv tanításának helyzete és fejlesztési feladatai. Új Pedagógiai Szemle. 2002/07-08.

Rechnitzer J. (2006): A Közép- és Délkelet-európai térség az európai regionális politikában. In: Baranyi B. (szerk.) Területfejlesztés, agrárium és regionalitás Magyarországon. Debreceni Egyetem Agrártudományi Centrum, Debrecen, 30-31.

Rőfi M. (2006): A Debreceni Egyetem regionális szerepe az Észak-alföldi régió versenyképességének megerősítésében. Doktori disszertáció. Interdiszciplináris Agrár- és Természettudományok Doktori Iskola. Debrecen, kézirat, 80.

Rubenson, K. (1975): Participation in Recurrent Education.CERI, OECD: Paris. In: Kozma T. (szerk.) Felnőttképzés és gazdaság. Pallas Debrecina 11: Debrecen.

Wiwczaroski T.B. (2003): A magyarországi felsőfokú szaknyelvoktatás diszciplínák közötti integrátori szerepének elhanyagolt volta. NyelvInfo. 3. 3-10.

KSH (1960, 1980, 1990, 2001, 2003, 2006): Census data of the Hungarian Statistical Office, Budapest.

(net 1) http://ec.europa/growthandjobs/areas/fiche10_en.htm

(net 2) http://europa.eu/scadplus/leg/en/cha/c11323.htm

(net 3) A nyelvek és Európa, http://europa.eu/languages/hu

(net 4) http://www.ec.europa.eu/public_opinion/archives/ebs/ebs 243_en.pdf

(net 5) www.ec.europa.eu/public_opinion/archives/ebs/ebs_237. en.pdf 